\title{
EU Integration and Trade: a Look from the Outside of the EU Eastern Border.
}

\author{
Oleksandr Shepotylo*, \\ Kyiv School of Economics and Kyiv Economics Institute
}

August, 2009

\begin{abstract}
:
This paper develops a methodology for trade policy analysis of costs and benefits of alternative regional integration scenarios, based on the disaggregated gravity equation, and applies it to calculate the impact of the EU enlargement on integration strategies of non-member countries.

In particular, the paper measures the impact of the $2004 \mathrm{EU}$ enlargement from the standpoint of Ukraine - a country that has been lost in transition; Ukraine moves away from CIS, but does not get closer to EU. This angle allows estimating the costs of non-integration that occurred due to trade and investment diversion, and forgone opportunity to carry our structural changes in the Ukrainian economy.

According to the results, EU accession would have had a small positive effect on total export volumes but would have dramatically changed the composition of Ukrainian exports by almost doubling exports of manufactured goods by 2007. The costs of non-integration accumulate towards the end of the investigated period. Projecting the results into the future clearly indicates that the benefits of EU accession for Ukraine would have been unambiguously positive and would overweight benefits of CIS integration.
\end{abstract}

JEL categories: C33, F12, F17

Keywords: gravity model, EU enlargement, Ukraine, CIS, heterogeneous firms, trade policy

\section{Introduction}

The studies of European Union (EU) enlargement mostly focus on the impact of the enlargement on the current and new EU members (e.g. Bussière et al. 2008, Nilsson, 2000, Baldwin, 1995 and 1997, Gros and Gonciarz 1996). This paper looks at the impact of EU enlargement from a different angle and estimates the costs of non-integration into EU. It develops a methodology for evaluating alternative regional integration scenarios.

*oshepotylo@eerc.kiev.ua 
Comparing costs and benefits of different integration scenarios, a policymaker decides on the best integration strategy for a county.

When an additional country joins a regional trade bloc, it imposes additional costs on outsiders due to trade and investment diversion ${ }^{1}$. The costs of non-integration are growing when more countries join the bloc, which triggers a new wave of enlargement, a so-called domino effect introduced by Baldwin (1993). For example, the enlargement of the European Economic Community (EEC) - a process that started in 1960s - induced integration of the members of the European Free Trade Agreement (EFTA) into the EEC: "The 1960s saw rapid discriminatory liberalisation with the EEC and EFTA. This had a dramatic effect on trade patterns. The EEC's share of trade with itself rose from 30 to 50 per cent. The share of EEC imports from other European nations stagnated or fell. This discrimination meant lost profit opportunities for exporters in both groups, but since the EEC market was more than twice the size of EFTA's market (and growing faster), the EEC club was far more attractive to exporting firms. This generated new political economy forces within the EFTA nations - forces that pushed for EEC membership." (Baldwin, 2008). The impact of the EEC formation on UK and its decision to join the EEC has been studied quite extensively (see Baldwin and Venables, 1994) for discussion of different approaches to evaluate the impact). In particular, Aitken (1973) used the gravity equation to evaluate trade creation and trade diversion generated by EEC and EFTA.

Currently, a similar process involving the EU and Commonwealth of Independent States (CIS) trading blocs is evolving. The differences in size and level of development between EU and CIS blocs imply that the EU bloc is more attractive and the opportunity costs of not-integrating into the EU are higher. Recently, EU has expanded by 12 new members, mostly by countries that for a long time had been important trading partners of CIS countries. At the same time, Georgia left the CIS in August, 2009, while Ukraine and Central Asia countries significantly reduced their involvement into the CIS programs. These developments indirectly indicate that the EU accession strategy looks as an increasingly attractive policy for the CIS countries. However, the literature says little on how the different integration scenarios can be compared.

What are the costs for the CIS countries of not integrating into EU? Do the costs of non-integration exceed the benefits of staying in the CIS? Empirically, this question

\footnotetext{
${ }^{1}$ In EFTA nations, the possibility of investment diversion was an important factor in the policy debates on EC membership: Baldwin et al. (1992) showed outflows of investments from EFTA countries due to the EEC enlargement.
} 
has not been studied and the primary goal of this paper is to evaluate the ex post costs of non-integration. To answer these questions, the paper focuses on Ukraine. De facto, Ukraine is a member of the CIS. However, Ukraine participates in the CIS programs very selectively and the Ukrainian parliament never ratified the CIS Charter. Moreover, after 2004, Ukraine explicitly declared the EU accession as its strategic goal and further reduced cooperation with the CIS. On the other hand, Ukraine is an eligible candidate for enlargement based on the geographical criteria. It is an important EU trading partner that moves towards EU both politically and economically. In February, 2008, the Ukraine has started a round of free trade agreement (FTA) negotiations with EU which is the next step towards the EU integration. The launch of negotiations followed the finalization of Ukraine's WTO accession process on February, $52008^{2}$, which was a prerequisite for FTA talks. Therefore, the advantage of looking at Ukraine while comparing costs and benefits of a deeper EU integration vs. deeper CIS integration is as follows. First, it is not a purely theoretical exercise but a question of practical importance. Did Ukraine make a right choice when declaring the EU integration as the policy priority? Second, the answer to this question gives guidance for policymakers of the EU and Ukraine for the decision on the future of the EU enlargement process.

How Ukrainian exports would look like if the country joined EU in 2004? To answer these questions, this paper develops a methodology that allows predicting trade patterns of Ukrainian exports in such a hypothetical situation. The offered method assumes that the main differences between being an EU member and being a typical CIS country stem from the changes in behavioral relationships of the parameters of the gravity equation rather than from the changes in factors that represent the gravity forces per se (see Egger, Pfaffermayr, and Schmidt 2006). By setting its regulatory framework in line with the EU standards, signing a deep FTA with EU, and, in the long run, achieving its final goal of becoming a full-fledged EU member, the Ukraine would gradually evolve from being a part of the CIS trading bloc with its distinct reliance on export of raw materials towards being a part of the EU trading block with a high degree of intraindustry trade in processed goods. Therefore, its trade patterns would become more in

\footnotetext{
${ }^{2}$ Ukraine submitted the application on November 20, 1993. On 5 February, 2008 it has been announced that Ukraine would become a member of the World Trade Organization (WTO) on June 4, 2008 after almost 15 years of negotiations
} 
line with the trade patterns of the Eastern European countries. The behavioral changes would come from better access to the EU market, changes in the institutional environment, deep reforms of the regulatory framework, and standardization of export and import regulations.

To capture the behavioral changes, the gravity model is estimated for two samples: one sample includes sixteen Eastern European countries - twelve EU member countries that recently joined EU (EU12) ${ }^{3}$ and four countries that are not member of the EU but are considered as candidates for enlargement in the future (EUC4) ${ }^{4}$; the other sample includes nine CIS countries ${ }^{5}$.

In addition to evaluating the behavioral change, the novelty of the paper lies in applying an estimation of the disaggregated gravity equation using the two stage procedure developed by Helpman, Melitz, and Rubinstein (2008) (henceforth HMR). The method explicitly deals with a substantial number of zero trade flows, and unobserved firm-level heterogeneity. Unlike the HMR method, we exploit both cross-sectional and time dimensions to remove the pair-specific fixed effects that can bias the cross-sectional results and estimate the impact of the EU accession on bilateral trade flows by the Hausman-Taylor method (Hausman and Taylor, 1981) treating the EU accession as an endogenous decision that correlates with variable and fixed costs of trade.

The model demonstrates substantial costs of not integrating into EU. If the Ukraine had became an EU member in 2004, it would have benefited from an increase in export volumes, redirection of trade from CIS trading partners towards the EU trading partners, and restructuring of exports from industrial products with low value added, primarily exports of raw materials, towards exports of manufactured products with high value added and exports of agriculture and food ${ }^{6}$. Export restructuring directed towards more complex, higher value added products is desirable for two reasons: first, it diversifies the economy and better protects against negative terms of trade shocks;

\footnotetext{
${ }^{3}$ EU12 includes: Cyprus, Czech Republic, Estonia, Hungary, Latvia, Lithuania, Malta, Poland, Slovakia, and Slovenia that joined EU in 2004; Bulgaria and Romania that joined EU in 2007.

${ }^{4}$ EUC4 includes: Albania, Croatia, Macedonia, and Turkey.

${ }^{5}$ CIS sample includes: Armenia, Azerbaijan, Belarus, Georgia, Kazakhstan, Kyrgyzstan, Moldova, Russia, and Ukraine. Tajikistan, Turkmenistan, and Uzbekistan are not included due to lack of export data.

${ }^{6}$ The second conclusion is conditional on the degree of trade liberalization of in agricultural and food products with old the EU members.
} 
second, production of high value added products is associated with higher future economic growth (Hausmann, Hwang, and Rodrik, 2007).

The evidence suggests that the benefits of the EU integration would have come not from the EU accession per se but from the gradual process of reforms, economic restructuring, and behavioral changes in the bilateral trade relationships with its trading partners. The initial losses from breaking the trade relationships with other CIS countries would be more than compensated later along the development path.

The structure of the paper is as follows. Section 2 compares existing trade patterns of the Eastern European countries with trade patterns of the CIS countries. Section 3 briefly discusses the methodological issues, presents a theoretical model and develops the estimation procedure. Section 4 discusses data. Section 5 presents estimation results for aggregated trade data and discusses advantages of the Hausman-Taylor method. It also presents estimated gains in disaggregated exports from the EU-Ukraine trade integration for two counterfactual experiments. Finally, Section 6 concludes.

\section{Trade patterns of EU and CIS countries: first glance at the data}

The theory of regionalism and preferential trade agreements (i.e. Baldwin, 1993; Baldwin et al. 2006) stresses that costs of non-integration into a regional trade bloc increase with the size of the bloc which, in turn, induces more countries to join the bloc due to a socalled "domino effect": by lowering trade barriers and improving market access, a discriminatory liberalization of trade within a trading bloc gives an edge to the companies located within the bloc over the outsiders and create additional incentives for multinational companies (MNC) to move their activities inside the bloc. This creates an additional pressure for inclusion on outside countries. Hence, once started, the process of regionalization captures ever-growing number of countries.

The story of the latest EU enlargement illustrates this point. The Council of Mutual Economic Assistance (CMEA) that, by 1989, included fifteen Soviet republics, six Eastern European countries - Bulgaria, Czechoslovakia, East Germany, Hungary, Romania, Poland -, and three other countries - Cuba, Mongolia, and Vietnam generated a 
substantial intra-bloc trade due to a high degree of economic and political integration ${ }^{7}$. The economic cooperation with the rest of the world was limited at best and in some instances prohibited. Since the beginning of transition, Eastern European countries and Baltic States have rapidly moved away from the Moscow-centered economic gravity towards the Brussels-centered one. As was correctly predicted by some scholars (i.e. Wang and Winters, 1991 Hamilton and Winters, 1992, and Baldwin, 1994), this led to the reorientation of their trade flows away from the CMEA countries towards the EU members. By 1995, Eastern European trade flows did not differ considerably from that of similar Western European countries and mostly exhausted the westward expansion of exports at the intensive margins of trade (Gros and Gonciarz (1996). This view is supported by a more recent World Bank (2005) report which shows that currently most of the EU12 countries trade above their potential or 'normal' level.

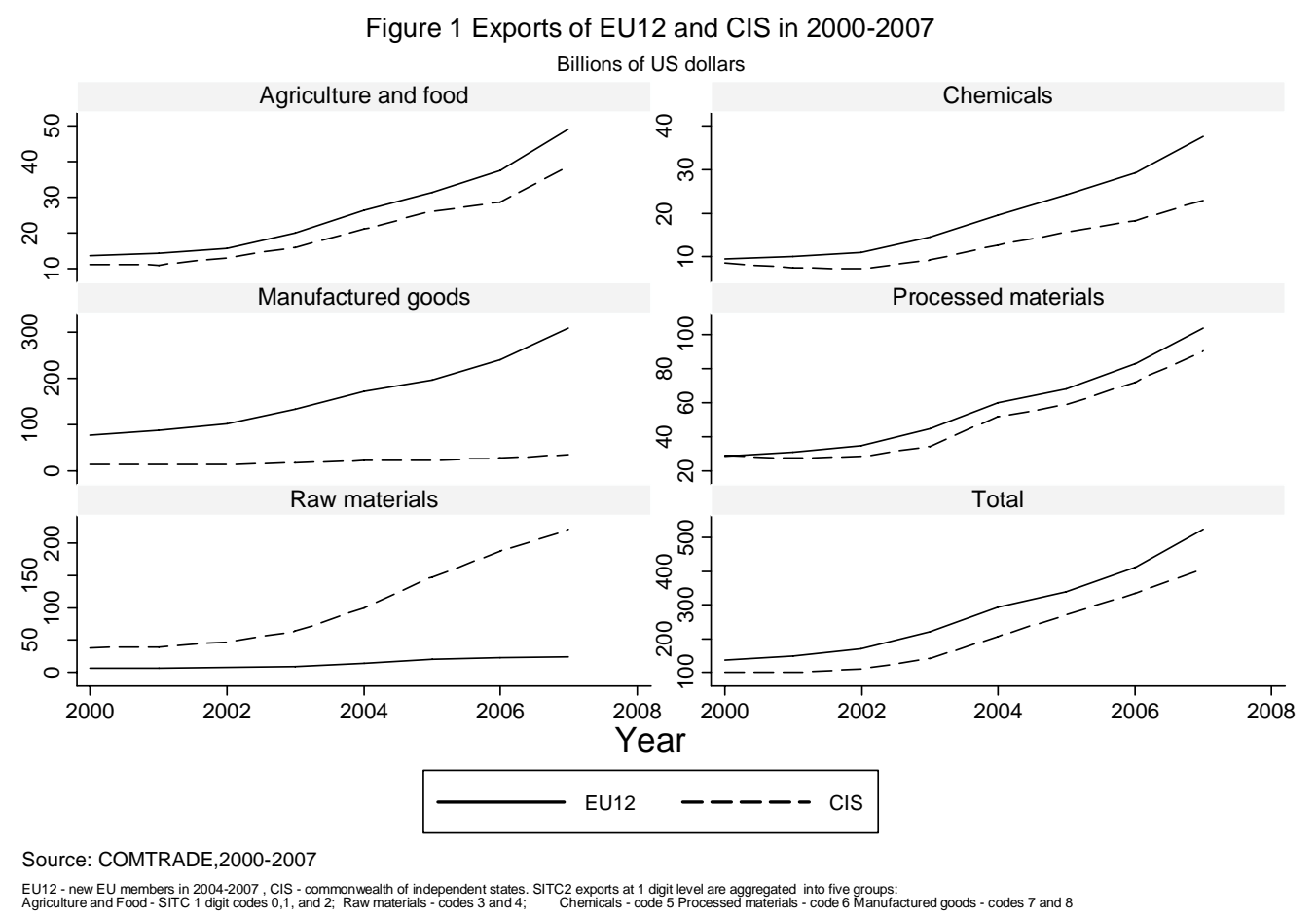

The accession of the EU12 countries into the EU in 2004 and 2007 finalized the process of integration. It further reduced trade barriers within the EU, mostly between EU12 countries themselves rather than between EU12 and the old EU members, and

\footnotetext{
${ }^{7}$ Pelzman (1977) has found that the integration of the socialist countries into CMEA has generated a substantial additional intra-bloc trade at the expense of the trade with the rest of the world. He estimated the value of trade creation effect at 13.2 billion of \$US in 1970.
} 
made the EU12 countries even more attractive destinations of FDI due to a favorable investment climate and convenient location for serving nearby markets ${ }^{8}$. Figure 1 reports exports from EU12 and CIS countries in five broad product categories as well as total exports. It reveals a spectacular expansion of exports of manufactured goods ${ }^{9}$ from the EU12 countries that exceeded 300 billion US dollars by 2007.

The 12 former Soviet Union republics (excluding Baltic States), on the other hand, have chosen to create an economic and political union, known as the Commonwealth of Independent States. Its formation was finalized in 1994 when the CIS Charter was ratified by 10 CIS members, except Turkmenistan and Ukraine which have chosen to participate in CIS selectively as associated members. However, the eastward expansion of EU and rapid economic growth of East Asia considerable weakened the economic attractiveness of CIS. In August 2009, Georgia officially denounced its membership, while Ukraine and several Central Asia countries were actively seeking closer economic relationships with EU and China consequently.

Similarly to the EU12, the CIS exports also expanded quite dramatically from 2000 to 2007; the driving force of the CIS growth, however, was the expansion of the export of raw materials that grew well over 200 billion dollars by 2007. At the same time, exports of manufactured goods from the CIS stagnated. One of the explanations of the stark differences between EU12 and CIS in terms of industrial composition of exports is that an intra-industry and intra-firm trade increased significantly in EU12 between 2000 and 2007. By attracting MNCs for locating their plants, EU12 has substantially increased intra-industry trade in high value added products and became an export platform for serving the CIS markets, while CIS countries failed to integrate into the global chains of production: the share of intermediate exports in the total export reached $20 \%$ in EU8 $8^{10}$ and only $6 \%$ in $\mathrm{CIS}^{11}$ : “...there has been substantial change over the course of the transition in the commodity composition and factor intensity of trade by the EU-8 and the SEE economies, relatively little

\footnotetext{
${ }^{8}$ For example, Slovakia is known as Detroit of the East. "Analysts say carmakers are drawn to Slovakia because it has a cheap but skilled work force, low taxes, weak labor unions, good highways and other logistics, and a strategic location in the geographic heart of Europe that's close to emerging markets in Russia, Ukraine and elsewhere in the former Soviet Union." http://abcnews.go.com/Business/wireStory?id=6360844

${ }^{9}$ Products 7 and 8 of SITC classification at one digit level of aggregation

${ }^{10}$ EU8: Eastern European countries that joined EU in 2004 not including Cyprus and Malta

${ }^{11}$ Pradeep Mitra, "Innovation, Inclusion and Integration," World Bank 2008
} 
has changed in these regards among the CIS countries, which effectively have been frozen in time. The result is that these countries are not active participants in the evolving international division of labor. The existing composition and factor intensity of exports puts the future growth prospects of the CIS at risk." (World Bank, 2005)

\section{Model and estimation methodology}

Suppose that, contrary to the fact, the Ukraine joined EU in 2004. The accession conditions would require the Ukraine to satisfy a list of certain criteria that include stable democratic institutions, respect for the rule of law, a functioning market economy, and an adjustment of the administrative structure. The deep political, economic and administrative reforms coupled with better access to the large EU market and proximity of the CIS markets would lead to a significant improvement of investment climate and a consequent behavioral change in the Ukrainian economy, its industrial structure, and composition of export.

To capture the behavioral differences between the CIS countries and EU12 countries, we separately estimate the gravity model at SITC two digit level of aggregation for the EU sample (exports from EU12, EUC4, and the Ukraine to 179 destination countries in 2000-2007) ${ }^{12}$, and for the CIS sample (exports from the CIS countries to 179 destination countries in 2000-2007). The time dimension is centered around the $2004 \mathrm{EU}$ enlargement episode. We further predict the Ukrainian exports based on the results for the two different samples and compare them in order to assess the differences in the export patterns.

The main underlying assumption is that if the Ukraine were a part of EU by 2004, its trade patterns were more in line with that of the EU12 members, hence, projecting the trade patterns of the Eastern and Central European countries on the characteristics and geographical location of the Ukraine would provide us with rough estimates of the potential export patterns under the EU integration scenario. Likewise, projecting the trade patterns of the CIS on Ukraine, would give us rough estimates of the trade patterns of Ukraine under the CIS integration scenario.

\footnotetext{
${ }^{12}$ We follow the "in-sample" approach of projecting trade flows because we capture country fixed effects. It would not be possible if Ukraine is excluded from the sample.
} 


\subsection{Estimation of the gravity model: econometric issues}

Due to prevalence of zero trade flows (an average share of non-zero trade flows across industries at SITC two digit level is 22 percent) and importance of distribution of firms within an industry for evaluation of changes in trade policy (e.g. Melitz, 2003; Bernard et al., 2003), we closely follow a modified version of the HMR model that takes into account zero trade flows and heterogeneity of firms. Ignoring zeroes in the bilateral trading matrix leads to the bias in the estimation of the gravity equation due to correlation between fixed costs of exporting and volumes of trade. Ignoring the heterogeneity of firms while evaluating potential gains from integration of the Ukraine into EU would miss the gains stemming from increasing productivity and restructuring of the product composition of exports.

The methodology is different from that of HMR in two important ways. First, we build a disaggregated model that allows for industry-level heterogeneity in trade costs. ${ }^{13}$ Looking at the disaggregated data allows us to analyze differences in export patterns of EU12 and CIS countries along the product dimension. We also are able to evaluate costs of non-integration for specific product categories that are important items in the Ukrainian export.

Second, we use a panel of exports in 2000-2007 while HMR evaluate their model on the cross-sectional data. The use of panel data allows looking at the dynamic impact of the EU enlargement. We treat an EU accession decision as an endogenous variable because it is linked to the graphical location of a country that correlates with the bilateral trade costs. Krugman 1991 stresses that FTAs are motivated by economic factors as well as political economy considerations. In an empirical investigation on economic determinants of FTA Baier and Bergstrand (2004) demonstrates that joining an FTA is more likely to be positive for countries that are closer, for pair of countries that are remote, for countries that are bigger and similar in the level of economic development.

\footnotetext{
${ }^{13}$ Hummels (1999) studied trade costs for 3,000 goods for New Zealand and Latin American imports and over 15,000 goods for US imports and found that trade costs vary significantly across industries. In particular, freight costs for manufacturing are lower than for commodities and agricultural products. For example, importing fruits and vegetables costs approximately 15 percent of the value of shipment, while importing road vehicles costs 2.1 percent.
} 
To deal with the endogeneity problem, we estimate the model by the HausmanTaylor method. It gained popularity in the trade literature due to its ability to remove biases in the estimation of the gravity equation and possibility to keep country specific time-invariant variables in the estimated equation. Serlenga and Shin (2007) tested performance of the Hausman-Taylor method in estimating the gravity equation of bilateral trade flows among 15 European countries in 1960-2001 and found that it provides more sensible results than fixed or random effect methods. McPherson and Trumbull (2008) used the Hausman-Taylor method to estimate the unrealized US-Cuban trade potential and also found that it is superior to the other popular methods of estimating panel data. Also, the time dimension helps us to remove biases stemming from unobserved industry and country-pair heterogeneity, and estimate the parameters of the model with greater precision.

\subsection{Model of Bilateral Export}

We modify the HMR set up by adding sectors indexed $k=1, \ldots, K$. Each country $i=1 \ldots C$ has $N_{k}^{i}$ firms that produce differentiated products in sector $k$. Let $c_{k l}^{i j}$ denote total consumption in country $j$ of a good $l$ that is produced by sector $k$ in country $i$.

\subsubsection{Consumers}

A representative consumer located in country $j$ has the utility function of the following form:

$$
U^{j}=\sum_{k=1}^{K}\left(\int_{l \in B_{k}^{j}} c_{k l}^{j} \frac{\sigma-1}{\sigma} d l\right)^{\theta_{k}}
$$

where $\sigma>1$ is the elasticity of substitution across different products. $\theta_{k}$ is the expenditure share of industry $k$ in total consumption. $B_{k}^{j}$ is the set of industry $k$ goods that are available for consumption in country $j$.

The optimal consumption derived from the optimization problem is:

$$
c_{k l}^{j}=\frac{\theta_{k} Y^{j}}{P_{k}^{j}}\left(\frac{p_{k l}^{j}}{P_{k}^{j}}\right)^{-\sigma}
$$


where $Y^{j}$ is the gross domestic product of country $\mathrm{j}$ that is equal to the total expenditures of country $\mathrm{j}$.

$$
P_{k}^{j}=\left(\int_{l \in B_{k}^{l}}\left(p_{k l}^{j}\right)^{1-\sigma} d l\right)^{\frac{1}{1-\sigma}}
$$

is the price index of industry $k$.

\subsubsection{Producers}

A country $i$ firm produces one unit of output with $w^{i} a$ units of labor. ${ }^{14} w^{i}$ is country specific, reflecting the differences in institutions, technology, and factor prices. Following Melitz (2003), we specify $a$ as a firm-specific parameter with the cumulative distribution function $G_{k}(a)$ over support $\left[a_{k \min }, a_{k \max }\right]$. Each firm is a monopolist over the production of a distinct good, but is small relative to the size of the market. A standard formula for monopolistic pricing implies that the firm charging the mill price as a constant mark-up over the marginal cost:

$$
p^{i}=\frac{\sigma}{\sigma-1} w^{i} a
$$

There are variable and fixed costs of delivering products to consumer markets that vary across industries. $T_{k}^{i j}$ is a melting iceberg transportation cost with $T_{k}^{i j}>1, T_{k}^{i i}=1 . F_{k}^{i j}$ is a fixed cost of exporting that is country-pair and industry specific with $F_{k}^{i j}>0, F_{k}^{i i}=0$. If the firm chooses to export its product to country $j$, consumers in country $j$ pay $p_{k}^{i j}=\frac{T_{k}^{i j} \sigma w^{i} a}{\sigma-1}$. It follows that the profit of the firm exporting to country $j$ is:

$$
\pi_{k}^{i j}(a)=\frac{\theta_{k}}{\sigma}\left[\frac{\sigma T_{k}^{i j} w^{i} a}{(\sigma-1) P_{k}^{j}}\right]^{1-\sigma} Y^{j}-F_{k}^{i j}
$$

The firm exports only if it receives positive operating profits, which is more likely if the productivity of the firm $\left(\frac{1}{a}\right)$ is high, the input price $\left(w^{i}\right)$ is low, and the fixed costs

\footnotetext{
${ }^{14}$ We consider a partial equilibrium model with fixed capital during the period being investigated. Labor is the only input that is perfectly mobile across industries, but immobile across countries.
} 
of exporting $\left(F_{k}^{i j}\right)$ are low. The least productive firm that exports to country $j$ has the productivity level $1 / a_{k}^{i j}$ determined as:

$$
\pi_{k}^{i j}\left(a_{k}^{i j}\right)=0 \Leftrightarrow \frac{\theta_{k}}{\sigma}\left[\frac{\sigma T_{k}^{i j} w^{i} a_{k}^{i j}}{(\sigma-1) P_{k}^{j}}\right]^{1-\sigma} Y^{j}=F_{k}^{i j}
$$

\subsubsection{Aggregation}

Out of $N_{k}^{i}$ firms that operate in country $i$ in industry $k$, only $N_{k}^{i} G_{k}\left(a_{k}^{i j}\right)$ firms export to country $j$. The aggregate export in industry $k$ from exporter $i$ to country $j$ is:

$$
\begin{aligned}
& X_{k}^{i j}=N_{k}^{i} G_{k}\left(a_{k}^{i j}\right) E\left(p_{k}^{i j}(a) C_{k}^{i j}(a) \mid \pi_{k}^{i j}(a)>0\right)=N_{k}^{i} \theta_{k} Y^{j} V_{k}^{i j}\left(\frac{\sigma T_{k}^{i j} w^{i}}{(\sigma-1) P_{k}^{j}}\right)^{1-\sigma} \text { if } \quad a_{k}^{i j}>a_{\min } \quad \text { and } \\
& X_{k}^{i j}=0 \text { otherwise, where } V_{k}^{i j}=\int_{a_{\min }}^{a_{k}^{i j}} a^{1-\sigma} d G_{k}(a) .
\end{aligned}
$$

The equation can be further simplified by using the equilibrium constraint on the output of sector k produced by country $\mathrm{i}$ which leads to the following export equation:

$$
X_{k}^{i j}=s_{k}^{i} Y^{i} Y^{j} V_{k}^{i j} \frac{\left(\frac{T_{k}^{i j}}{P_{k}^{j}}\right)^{1-\sigma}}{\sum_{j=1}^{C}\left(\frac{T_{k}^{i j}}{P_{k}^{j}}\right)^{1-\sigma} Y^{j} V_{k}^{i j}}
$$

\subsection{Parameterization and Estimation}

In the following discussion we consider industry-specific equations but drop an index $\mathrm{k}$ to simplify notation.

\subsubsection{Selection of firms}

Define a latent variable as:

$$
\Psi_{t}^{i j}=\frac{\frac{\theta}{\sigma}\left[\frac{\sigma T^{i j} w_{t}^{i} a_{\min }}{(\sigma-1) P_{t}^{j}}\right]^{1-\sigma} Y_{t}^{j}}{F_{t}^{i j}}
$$

A positive export is observed if $\Psi_{t}^{i j} \geq 1$ that is determined by the ratio of firm level profits to the fixed costs of exporting. Other things being equal the level of the fixed costs 
plays the crucial role in defining trading partners with positive trade flows. We assume that the fixed costs are country-pair specific but not firm-specific even though they can vary from one product to another. Suppose that fixed costs have the following functional form $F_{t}^{i j}=\exp \left(\kappa_{1} \phi^{i}+\kappa_{2} \phi^{j}+\kappa_{3} \phi^{i j}-\theta_{t}^{i j}\right)$, where $\phi^{i}$ represents fixed costs specific to the exporting country, $\phi^{j}$ represents fixed costs specific to the importing country, $\phi^{i i}$ represents country-pair-specific fixed costs, and $\theta_{t}^{i j}$ represents country-pair-specific random components.

Trade costs associated with the shipping of a unit of good from country $i$ to country $j$ are modeled by assuming the commonly used functional form:

$$
\left(T_{t}^{i j}\right)^{\sigma-1}=\left(\operatorname{dist}^{i j}\right)^{\rho} \exp \left(Z \gamma-u_{t}^{i j}\right),
$$

where $\operatorname{dist}^{i j}$ is the distance between countries $i$ and $j, Z$ is a set of additional variables that determine trade costs, $\gamma$ is the vector of coefficients associated with $Z$, and $u_{t}^{i j}$ is the error term that include all unobservable trade costs that are allowed to change over time. In particular, we assume that one of the determinants of trade costs is the current status of exporting county with respect to EU membership, $E U_{t}^{i}$. It captures the effect of the integration process in terms of country's exports. Also, we introduce a bilateral indicator variable bothEU $U_{t}^{i j}$ that takes value of 1 if both trading countries are full EU members and zero otherwise. It captures the effect of the EU accession on trade within EU relative to trade that is external to EU.

$u_{t}^{i j}$ includes all time varying and pair specific trade costs that are not directly controlled for in the gravity equation. Trade costs change over time as a result of integration processes in Europe and Central Asia region. Countries that are willing to join EU are required to satisfy certain economic, geographical, and political criteria and carry out wide range of economic reforms. Political reasons play an important role in determining trading pairs and products especially in CIS $^{15}$. All those considerations do

\footnotetext{
${ }^{15}$ Russian Federation uses trade policies as a tool of political influence particularly frequently. For example, it banned exports of wine form Georgia and Moldova in 2006, exports of fish from Lativa in 2006. The heated disputed over natural gas prices with Ukraine in 2006 and 2008 was also seen by many as a political tool to influence the political situation in Ukraine.
} 
not allow us to treat EU related variables as endogenous and require corrections to the estimation procedure that are discussed later.

Taking logs of both sides of equation (8) yields:

$$
\begin{aligned}
& \psi_{t}^{i j}=\ln \Psi_{t}^{i j}=\zeta_{0}+\ln Y_{t}^{j}-\rho \ln d i s t^{i j}-Z \gamma+ \\
& (1-\sigma) \ln w_{t}^{i}-\phi^{i}-\phi^{j}-\kappa \phi^{i j}+\lambda_{t}^{i j}
\end{aligned}
$$

where $\lambda_{k t}^{i j}=-(1-\sigma) \ln P_{t}^{j}+\theta_{t}^{i j}+u_{t}^{i j}=d^{i}+d^{j}+d_{t}+\mu_{t}^{i j}$ Finally, we assume that $\mu \sim N\left(0, \sigma_{\mu}^{2}\right)$.

Under normality, both sides of equation (10) are divided by $\sigma_{\mu}$ to normalize the selection equation:

$$
\begin{aligned}
\delta_{t}^{i j}= & \operatorname{Prob}\left(\mathrm{X}_{\mathrm{t}}^{\mathrm{ij}}>0 \mid \Psi_{\mathrm{t}}^{\mathrm{ij}}\right)=\Phi\left(\zeta_{0}+\ln Y_{t}^{j}-\rho \ln d i s t^{i j}-Z \gamma\right. \\
& \left.+(1-\sigma) \ln w_{t}^{i}-\kappa_{1} \phi^{i}-\kappa_{2} \phi^{j}-\kappa_{3} \phi^{i j}+d^{i}+d^{j}+d_{t}+\mu_{t}^{i j}\right)
\end{aligned}
$$

where $\Phi(\cdot)$ is the unit-normal cdf.

\subsubsection{Gravity equation}

Taking the logs of both sides of equation (7) and substituting for $T_{t}^{i j}$ yields:

$\ln X_{t}^{i j}=\ln s^{i}+\ln Y_{t}^{i}+\ln Y_{t}^{j}-\rho \ln d i s t^{i j}-Z \gamma+\ln V_{t}^{i j}-(1-\sigma) \ln P_{t}^{j}-\ln M R T_{t}^{i}+u_{t}^{i j}$

where $\ln M R T_{t}^{i}=\ln \left(\sum_{j=1}^{C}\left(\frac{T_{t}^{i j}}{P_{t}^{j}}\right)^{1-\sigma} Y_{t}^{j} V_{t}^{i j}\right)$ is the multilateral resistance term, an integral measure of trade barriers of a country vis-à-vis all its trading partners (Anderson and van Wincoop, 2003), which accounts for the endogenous and simultaneous determination of trade flows across all countries. The multilateral resistance term, $\ln M R T_{t}^{i}$, and price level, $\ln P_{t}^{j}$, are not observable, and according to theory is simultaneously determined for all countries.

Following HMR, we use the information acquired at the first stage of the estimation by identifying $E\left(\ln V_{t}^{i j}+u_{t}^{i j} \mid X_{t}^{i j}>0\right)=b_{0} \hat{\eta}_{t}^{i j}+\sum_{m=1}^{3} b_{m}\left(\hat{\psi}_{t}^{i j}\right)^{m}$, where $\hat{\eta}_{t}^{i j}$ is the traditional inverse Mills ratio that accounts for the sample selection bias and the polynomial of degree three in $\hat{\psi}_{t}^{i j}=\hat{\eta}_{t}^{i j}+\Phi^{-1}\left(\hat{\delta}_{t}^{i j}\right)$ corrects for the firm level heterogeneity. As shown by HMR, the polynomial of degree 3 is a sufficiently flexible 
and accurate approximation of the underlying unknown distribution of productivities, $G(a)$. Finally, the gravity equation takes the following form:

$$
\begin{aligned}
& \ln X_{t}^{i j}=\ln s_{i}+\ln Y_{t}^{i}+\ln Y_{t}^{j}+b_{0} \hat{\eta}_{t}^{i j}+\sum_{m=1}^{3} b_{m}\left(\hat{\psi}_{t}^{i j}\right)^{m}-\rho \ln d i s t^{i j}-Z \gamma \\
& +\omega_{t}^{i j}, \mathrm{t}=1,2 \ldots \mathrm{T}
\end{aligned}
$$

where $\omega_{t}^{i j}=-(1-\sigma) P_{t}^{j}-\ln M R T_{t}^{i}+u_{t}^{i j}$.

A traditional approach to deal with the multilateral resistance term and unobserved price level is by introducing country fixed effects (see Baldwin and Taglioni, 2006, for a discussion on the usage of fixed effects in the gravity equation). Therefore, we assume that the error term can be represented as $\omega_{t}^{i j}=d_{i}+d_{j}+d_{t}+\omega_{i j}+\varepsilon_{t}^{i j}$. In this specification, we have exporter and importer fixed effects, common time effect, and pair specific component, $\omega_{i j}$, that is random and independently distributed across countrypairs. We also allow for the correlation between $\omega_{i j}$ and the components of vector $\mathrm{Z}$ that are related to the integration decisions. To solve the endogeneity problem, we apply the Hausman-Taylor method which uses time-varying variables that are not correlated with $\omega_{i j}$ as instruments for endogenous components of $\mathrm{Z}$.

\section{Data sources and variable definitions}

\subsection{Dependent Variable}

Table 1 presents the definitions of variables and sources of data. In the empirical analysis, we estimate unidirectional bilateral exports from twelve new EU members (EU12), four EU candidate countries (EUC4), and nine CIS countries to 179 destination countries in 2000-2007 at two digit level of SITC classification. The export data measured in current US dollars are acquired from the COMTRADE database. Table A2 in the appendix presents the summary statistics of exports by exporting countries.

\subsection{Independent Variables}

We differentiate all countries in the sample as non-members, EU candidates, and full EU members. A change in the status from a non-member to a candidate is determined 
according to the announcements made by the European Commission, which are taken from its website. Based on the acquired information, we construct an $\boldsymbol{E} \boldsymbol{U}_{\boldsymbol{i t}}$ variable that indicates the current status of a country with regard to the EU membership. It takes the value of 1 if a country is officially announced as a candidate for accession, 2 if a country is a member of $\mathrm{EU}$, and 0 otherwise. By including this variable, we capture the impact of the change in the EU status on the overall export within a SITC two digit category. During the investigated period two countries were officially announced candidate countries: Croatia in June 2004 and Macedonia in December 2006. All EU12 countries and Turkey have been announced candidates for accession before 2000 while Albania has not received an EU candidate status by 2007. In addition to the $\boldsymbol{E} \boldsymbol{U}_{i t}$ variable, a binary variable bothE $\boldsymbol{U}_{i j t}$ is introduced to indicate whether both trading countries are the EU members or not. It captures the impact of the EU accession on exports within the EU. By including the two variables we can measure the direct impact of the EU integration on exports within and outside of EU.

GDP in current US dollars and population data were acquired from the 2008 World Development Indicators (WDI). In addition, we include a set of variables that are routinely used in the gravity models to control for trade costs, geographical location, historical ties, and cultural similarities. Geographical characteristics and distance between countries were collected from the Centre D'Etudes Prospectives et D'Informations Internationales (CEPII) in Paris. Colony and contiguity dummies (whether one of the countries in the country-pair was ever a colony of the other country and whether countries are located on the same continent) were used to control for pairspecific trade costs that are not directly related to distance. Finally, same religion is a binary variable that takes value of 1 if majority of population in both trading countries share the same religion and 0 otherwise to capture the effect of cultural similarities between two nations on trade.

\subsection{Selection Variables}

For identification of the first stage parameters, we chose two variables that enter the selection equation, but not the gravity equation. The common language dummy controls for the pair-specific fixed costs related to adapting to cultural and linguistic barriers 
between two countries (translation costs, advertising etc.). To control for country-specific fixed costs related to regulatory quality in exporting and importing countries, we used governance indicators of regulatory quality acquired from the World Bank "Governance matters, 2007" database constructed by Kaufmann, Kray, and Mastruzzi (2007). The index of the regulatory quality captures the effectiveness of bureaucracy, amount of red tape, and quality of policies and regulations that encourage free trade ${ }^{16}$.

Exclusion of the variables from the gravity equation can be justified by the fact that the first variable is found as not robust determinant of exports at intensive margin as demonstrated by HMR and Martin and Pham (2008). In addition, we control for cultural differences in the gravity equation by including a common religion dummy. The regulatory quality variable measures effectiveness of government regulations which affects all exporters and is not linked to the volume of export.

\begin{tabular}{|c|c|c|}
\hline Variables & Description & Sources \\
\hline \multicolumn{3}{|c|}{ Dependent variables } \\
\hline Export & $\begin{array}{l}\text { Export from } i \text { to } \mathrm{j} \text { in sector } \mathrm{k} \text {, in thousands of current \$US. COMTRADE exports data aggregated to two digit } \\
\text { SITC2 sectors in 2000-2007 }\end{array}$ & $\begin{array}{l}\text { United Nations Commodity } \\
\text { Trade Statistics Database }\end{array}$ \\
\hline \multicolumn{3}{|c|}{ Endogenous variables } \\
\hline EU & $\begin{array}{l}\mathrm{EU} \text { is an indicator variable that takes value of } 1 \text { if country } \mathrm{i} \text { was officially announced as a candidate for the EU } \\
\text { accession and takes value of } 2 \text { if country } i \text { is the EU member, otherwise it takes value of } 0 .\end{array}$ & \\
\hline bothEU & Binary variable that takes value of 1 if trading countries $i$ and $j$ are both members of EU and 0 otherwise & \\
\hline \multicolumn{3}{|c|}{ Independent variables } \\
\hline $\mathrm{s}$ & Sector share in total value added. GTAP sectors are mapped to SITC2 sectors & GTAP Input-output tables \\
\hline $\begin{array}{l}\text { GDP } \\
\text { Population }\end{array}$ & $\begin{array}{l}\text { Gross domestic product, in current \$US. } \\
\text { Population }\end{array}$ & $\begin{array}{l}\text { World development indicators } \\
\text { World development indicators }\end{array}$ \\
\hline Dist & $\begin{array}{l}\text { distance between the biggest cities of countries } \mathrm{i} \text { and } \mathrm{j} . \mathrm{dkl} \text { is the distance between cities } \mathrm{k} \text { and } 1 \text {. (Head and Mayer, } \\
\qquad d_{i j}=\sum_{k \in i}\left(\text { pop }_{k} / \mathrm{pop}\right) \sum_{l \in j}\left(\mathrm{pop}_{\mathrm{f}} / \mathrm{pop}_{\mathrm{j}}\right) d_{k l}\end{array}$ & CEPII \\
\hline Contig & Binary variable indicating whether the two countries are contiguous, 1 or not, 0. & CEPII \\
\hline Colony & Binary variable set equal to 1 if one of the countries used to be a colony of the other country. & CEPII \\
\hline Same continent & $\begin{array}{l}\text { Binary variable, set equal to } 1 \text { if countries } i \text { and } j \text { located on the same continent. Mapping of countries to continents } \\
\text { was taken from CEPII geodata. }\end{array}$ & Author's calculations \\
\hline Same religion & $\begin{array}{l}\text { Binary variable set equal to } 1 \text { if countries } i \text { and } j \text { share the same religion. Countries are qualified into one ot the six } \\
\text { major religions - buddhist, catholic, hindu, muslim, orthodox, protestant - according to the following rule: if at least } \\
50 \text { percent of population in country i are following one of the major religions then the country i has major religion, } \\
\text { otherwise the country } i \text { is qualified as having no distinct religion affiliation. Data on religious composition of } \\
\text { population is taken from CIA - The World Factbook. }\end{array}$ & Author's calculations \\
\hline \multicolumn{3}{|l|}{ Selection variables } \\
\hline Common language & Binary variable indicating whether countries $i$ and $j$ share a common language. & CEPII \\
\hline Reg. quality & $\begin{array}{l}\text { Regulatory quality index measures the ability of the government to formulate and implement sound policies and } \\
\text { regulations that permit and promote private sector development (Kaufmann, Kraay and Mastruzzi, 2007) }\end{array}$ & Governance matters, 2007 \\
\hline
\end{tabular}

\footnotetext{
${ }^{16}$ Since data on regulatory quality before 2002 are available on a biennial basis, we imputed the missing values for 2001 by using average values between 2000 and 2002 .
} 


\section{Results}

This section has the following goals. First, we calibrate the estimation methodology by comparing how the Hausman-Taylor method performs relative to the OLS and fixed effect methods at the aggregate level. Second, we present and discuss the results estimated by the two stage HT procedure at the level of SITC two digit products. Finally, we calculate export gains form the EU accession of the Ukraine and discuss the main findings.

\subsection{Aggregate results}

Table 2 reports the estimation results performed by the OLS (columns 1 and 2), two-stage Hausman-Taylor (HT) ${ }^{17}$ (columns 3 and 4), and two-stage fixed effect (FE) methods (columns 5 and 6) for the EU and CIS samples. All regressions include exporting- and importing-country fixed effects, time dummies and a constant term. The country-pair cluster-robust standard errors are presented in parentheses. Three points are worth mentioning. First, there are important and statistically significant behavioral differences between the two samples regardless of the estimation procedure. Exports from the CIS countries are less elastic with respect to the size of an importing economy and more elastic with respect to the GDP of an exporting country. CIS exports are less elastic in absolute value with respect to the bilateral distance which reflects a higher geographical concentration of trade EU12 within the EU trade area. Second, the change in the status of EU integration does not have a significant effect on the aggregate export. Third, coefficients of the polynomial approximating $\ln V_{t}^{i j}$ and inverse mills ratio $\eta_{t}^{i j}$ are jointly significant when the two stage procedure is implemented as indicated by the test at the bottom of the table which stresses the importance of including the first stage variables into the gravity equation.

\footnotetext{
${ }^{17}$ In the case of the CIS sample, results of the random effect method are reported because EU and bothEU variables are not included.
} 
Table 2 Gravity model of aggregate trade flows

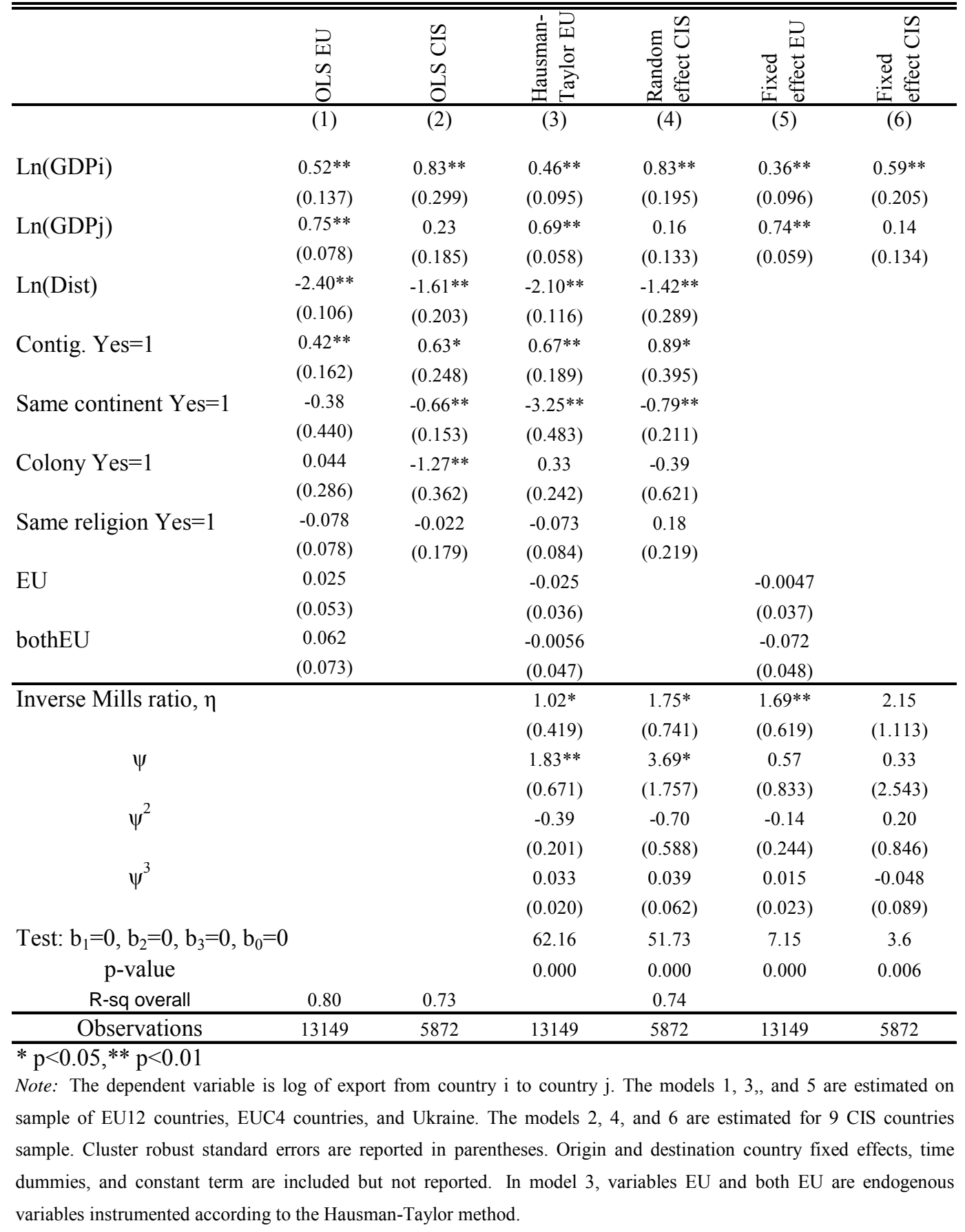


Table 3 Actual and predicted export of Ukraine in 2000-2007

\begin{tabular}{|c|c|c|c|c|c|c|c|c|c|c|}
\hline & \multicolumn{10}{|c|}{ A Cumulative export, billions of $\$$ US in $2000-2007$} \\
\hline & \multirow[t]{2}{*}{ Actual } & \multicolumn{3}{|c|}{ OLS method } & \multicolumn{3}{|c|}{2 stage HT method } & \multicolumn{3}{|c|}{ FE } \\
\hline & & EU1 & EU2 & CIS & EU1 & EU2 & CIS & EU1 & EU2 & CIS \\
\hline \multicolumn{11}{|l|}{ Region } \\
\hline $\mathrm{CIS}$ & 68.30 & 73.50 & 75.00 & 754.00 & 74.20 & 73.70 & 77.40 & 76.00 & 75.90 & 67.90 \\
\hline China & 4.94 & 3.93 & 4.01 & 12.40 & 5.51 & 5.47 & 5.34 & 5.71 & 5.71 & 5.37 \\
\hline EU12 & 25.70 & 22.40 & 23.90 & 42.40 & 27.40 & 27.10 & 26.10 & 28.30 & 27.80 & 26.60 \\
\hline EU15 & 39.20 & 137.00 & 146.00 & 164.00 & 42.50 & 42.20 & 40.90 & 39.90 & 39.30 & 39.90 \\
\hline Rest of Europe & 10.80 & 14.70 & 15.00 & 41.80 & 11.20 & 11.10 & 11.00 & 11.40 & 11.40 & 10.50 \\
\hline Rest of the world & 54.80 & 54.30 & 55.30 & 69.70 & 50.50 & 50.20 & 49.90 & 52.90 & 52.90 & 52.10 \\
\hline Turkey & 13.90 & 13.00 & 13.20 & 22.10 & 14.00 & 13.90 & 13.10 & 14.90 & 14.90 & 14.10 \\
\hline \multirow[t]{4}{*}{ Total } & 218.00 & 319.00 & 332.00 & 1110.00 & 225.00 & 224.00 & 224.00 & 229.00 & 228.00 & 217.00 \\
\hline & \multicolumn{10}{|c|}{ B Cumulative export, billions of \$US in 2000-2003 } \\
\hline & \multirow[t]{2}{*}{ Actual } & \multicolumn{3}{|c|}{ OLS method } & \multicolumn{3}{|c|}{2 stage HT method } & \multicolumn{3}{|c|}{ FE } \\
\hline & & EU1 & EU2 & CIS & EU1 & EU2 & CIS & EU1 & EU2 & CIS \\
\hline \multicolumn{11}{|l|}{ Region } \\
\hline CIS & 19.10 & 15.80 & 15.80 & 217.00 & 16.50 & 16.70 & 23.20 & 15.90 & 16.00 & 18.50 \\
\hline China & 2.74 & 1.05 & 1.05 & 3.81 & 1.38 & 1.40 & 1.67 & 1.38 & 1.38 & 1.50 \\
\hline EU12 & 9.16 & 5.91 & 5.91 & 12.90 & 6.99 & 7.08 & 8.08 & 7.02 & 7.29 & 7.67 \\
\hline EU15 & 13.20 & 40.80 & 40.80 & 51.80 & 12.90 & 13.10 & 13.10 & 11.50 & 11.90 & 11.50 \\
\hline Rest of Europe & 3.72 & 3.68 & 3.68 & 12.70 & 2.90 & 2.93 & 3.47 & 2.79 & 2.80 & 3.16 \\
\hline Rest of the world & 16.90 & 16.90 & 16.90 & 22.20 & 14.40 & 14.60 & 15.30 & 14.80 & 14.90 & 15.10 \\
\hline Turkey & 4.01 & 3.20 & 3.20 & 6.60 & 3.64 & 3.68 & 4.04 & 3.58 & 3.59 & 3.90 \\
\hline \multirow[t]{4}{*}{ Total } & 68.80 & 87.30 & 87.30 & 327.00 & 58.80 & 59.50 & 68.90 & 57.00 & 57.80 & 61.30 \\
\hline & \multicolumn{10}{|c|}{ C Cumulative export, billions of $\$$ US in 2004-2007 } \\
\hline & Actual & \multicolumn{3}{|c|}{ OLS method } & \multicolumn{3}{|c|}{2 stage HT method } & \multicolumn{3}{|c|}{ FE } \\
\hline & & EU1 & EU2 & CIS & EU1 & EU2 & CIS & EU1 & EU2 & CIS \\
\hline \multicolumn{11}{|l|}{ Region } \\
\hline $\mathrm{CIS}$ & 49.20 & 57.80 & 59.20 & 537.00 & 57.70 & 57.00 & 54.20 & 60.00 & 59.90 & 49.50 \\
\hline China & 2.20 & 2.88 & 2.96 & 8.62 & 4.13 & 4.08 & 3.67 & 4.34 & 4.33 & 3.87 \\
\hline EU12 & 16.50 & 16.50 & 18.00 & 29.50 & 20.40 & 20.00 & 18.10 & 21.30 & 20.50 & 19.00 \\
\hline EU15 & 26.00 & 96.50 & 105.00 & 112.00 & 29.50 & 29.10 & 27.90 & 28.40 & 27.40 & 28.50 \\
\hline Rest of Europe & 7.05 & 11.00 & 11.30 & 29.10 & 8.26 & 8.15 & 7.56 & 8.62 & 8.60 & 7.36 \\
\hline Rest of the world & 37.90 & 37.40 & 38.40 & 47.50 & 36.10 & 35.60 & 34.60 & 38.10 & 38.00 & 37.00 \\
\hline Turkey & 9.93 & 9.79 & 10.00 & 15.50 & 10.40 & 10.20 & 9.07 & 11.30 & 11.30 & 10.20 \\
\hline Total & 149.00 & 232.00 & 245.00 & 780.00 & 166.00 & 164.00 & 155.00 & 172.00 & 170.00 & 155.00 \\
\hline
\end{tabular}

How well the three estimation methods discussed above can predict the geographical pattern of the aggregate export? Panel A of Table 3 shows actual and projected exports from Ukraine to its trading partners in 2000-2007. The first column reports the actual exports. In addition, it reports predictions generated by the OLS, twostage HT, and two-stage FE methods under three different scenarios: EU1 - Ukraine has been announced an EU accession candidate in 2000, EU2 - in addition to EU1, Ukraine 
has joined EU in 2004, CIS - Ukraine integrated into CIS trading bloc ${ }^{18}$. The OLS method performs poorly in explaining geographical distribution of export. It predicts that deeper CIS integration of Ukraine would increase aggregate export more than four times relative to the actual export. Export to CIS would have increased more than tenfold! It is hard to imagine what would cause such an explosion of trade. Such an implausible result casts substantial doubts on the applicability of the OLS method to predict export flows. The two-stage HT and FE methods, on the other hand, generate projections that are in remarkable agreement with each other and with the actual data.

According to the two-stage HT results, there are very small differences in exports generated by the CIS and EU integration scenarios which bring a conclusion that at the aggregate level, there are very small benefits of the EU integration. It seems that this result confirms the World Bank (2005) findings that the CIS countries are as well integrated into the global trading system as a typical Eastern European country and therefore further integration with EU would not bring any substantial gains to the exports of the CIS countries. However, more careful investigation of the results presented in panels $\mathrm{B}$ and $\mathrm{C}$ reveals very interesting dynamics.

Panel B of Table 3 reports the pre-accession patterns of exports. The HT method predicts that if Ukraine had chosen deeper integration into the CIS bloc, its pre-accession export levels would have been very similar to the actual ones, while the deeper EU integration would lead to somewhat lower levels of exports. Under any integration scenario, post-accession exports, reported in the panel C, would have been higher relative to the actual exports. For example, the total export in 2004-2007 under EU2 would have been $10 \%$ higher than the actual exports. Importantly, the export gains under the EU1 and EU2 scenarios would have been higher relative to the CIS scenario. Predictions generated by the pair fixed effect method show slightly lower export levels before integration and slightly higher export levels after integration relative to the HT method.

Figure 2 reports time series of Ukrainian actual exports as well as predicted exports for EU2 and CIS scenarios to four groups of countries: CIS, EU12, EU15, and the rest of the World. The benefits of the EU integration for the Ukraine would have started playing an important role after 2004 and would accumulate over time. This pattern

\footnotetext{
${ }^{18}$ The CIS scenario models Ukraine as a typical CIS country.
} 
reflects that integration into EU markets is a long and complex process that does not generates immediate gains, still brings considerable rewards in the long run.

Figure 2 Actual and predicted exports by regions

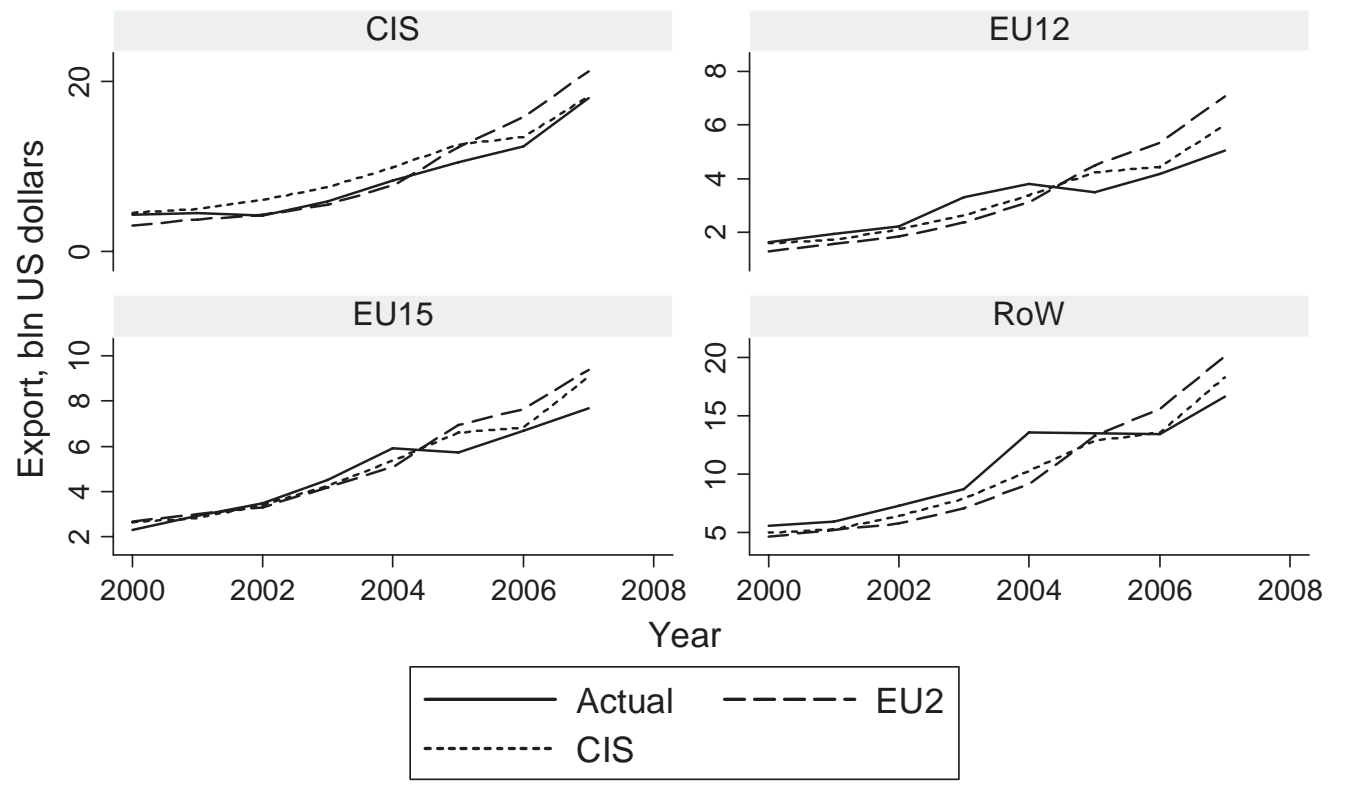

Actual exports compared with two counterfactual scenarios: $1 \mathrm{EU}$ - Ukraine became EU member in 2004, 2 CIS - Ukraine integrated in CIS Destination countries are aggregated into four regions: CIS - countries of commonwealth of independent states, EU15 - countries that became EU members before 2004, EU12 - countries that became EU members after 2004, RoW - all other countries

The results may be sensitive to the choice of the countries in the sample. As a robustness check, we estimated the model using an enlarged EU sample that included "old" EU members. The results remain the same qualitatively, while there were some minor quantitative changes.

To summarize, the analysis of aggregate trade flows reveals that any integration strategy would be preferable to the current situation of being lost in transition: currently, Ukraine is moving away from CIS but not getting closer to EU. The benefits of the EU integration are higher relative to the CIS integration: by 2007, the deeper EU integration would generate higher export volumes to any trading partner. The change in the accession status would not play an important role for determination of the export levels, while the behavioral change would be the major driving force of export expansion. From the methodological standpoint, taking into account the selection of the trading partners and industry-level heterogeneity are important in generating plausible export predictions: both the two-stage HT and two-stage FE methods are preferable to the one-stage OLS method of estimating the export levels. 


\subsection{Impact of the change in the EU status on export at 2 digit SITC level}

As the next step, we estimate the gravity model at the level of SITC two digit products for the EU and CIS samples using the two-stage HT method. The HT method is preferred over the FE method because it allows controlling for the endogeneity of the Table 4 Two stage Hausman-Taylor results at SITC 2 digit level

\begin{tabular}{|c|c|c|c|c|c|c|c|c|}
\hline \multirow[b]{2}{*}{ SITC 2} & \multicolumn{4}{|c|}{ First stage, Probit } & \multicolumn{4}{|c|}{ Second stage, HT method } \\
\hline & eu & bothEU & chi2 & Observations & eu & bothEU & chi2 & Observations \\
\hline 2 & -0.37 ** & $1.03^{* *}$ & 2933.5 & 22559 & $-1.01^{\star \star}$ & $2.23^{\star \star}$ & 1827.8 & 5590 \\
\hline 4 & -0.09 & 0.17 & 4334.2 & 23766 & $-0.29 *$ & $0.61^{\star \star}$ & 2450.7 & 6873 \\
\hline 22 & 0.04 & 0.14 & 1856.5 & 15759 & 0.11 & 0.26 & 1095 & 2925 \\
\hline 24 & $0.12^{*}$ & $0.29 * *$ & 3216.3 & 20230 & -0.11 & -0.21 & 2326.7 & 6087 \\
\hline 27 & $0.11^{*}$ & -0.17 & 3235.6 & 22678 & -0.13 & -0.09 & 2110.9 & 5605 \\
\hline 28 & 0.00 & -0.03 & 2292.8 & 15895 & 0.01 & $0.34^{*}$ & 1452.1 & 3900 \\
\hline 32 & $0.26^{\star \star}$ & -0.18 & 1415.5 & 16303 & 0.41 & $-0.46^{*}$ & 1080.5 & 2844 \\
\hline 33 & 0.08 & 0.01 & 3999.2 & 23511 & $-0.51^{\star \star}$ & $0.39^{\star *}$ & 2466 & 7223 \\
\hline 42 & -0.12 & $0.34^{\star \star}$ & 2487.6 & 19975 & $-0.84^{\star \star}$ & $0.87^{*}$ & 1139 & 3193 \\
\hline 51 & $-0.12^{*}$ & 0.13 & 3682.4 & 22542 & $0.26^{* *}$ & -0.01 & 2860.1 & 7493 \\
\hline 52 & $-0.12^{*}$ & 0.05 & 2771.3 & 22287 & -0.31 & $0.28 *$ & 2128.4 & 6691 \\
\hline 56 & $0.12^{*}$ & 0.00 & 1778.4 & 19295 & -0.25 & 0.03 & 1123.2 & 3221 \\
\hline 64 & $-0.21^{\star *}$ & -0.02 & 3810.6 & 23783 & $-0.74^{\star \star}$ & $0.45^{\star \star}$ & 3207.9 & 9462 \\
\hline 66 & 0.00 & $-0.22^{\star}$ & 3666 & 24038 & 0.03 & 0.2 & 4714.4 & 10154 \\
\hline 67 & -0.06 & 0.05 & 3258.5 & 23511 & $-0.24^{\star \star}$ & $0.49 * \star$ & 4476.3 & 9381 \\
\hline 68 & $0.11^{*}$ & $0.30^{* *}$ & 3664.3 & 22151 & 0.11 & -0.21 & 2728.7 & 6663 \\
\hline 69 & 0.09 & -0.02 & 3963.1 & 23766 & $0.12^{*}$ & -0.03 & 7061.5 & 11778 \\
\hline 71 & 0.04 & -0.17 & 4323.6 & 23630 & $-0.18^{*}$ & $0.30^{*}$ & 3700.1 & 9832 \\
\hline 72 & 0.02 & -0.08 & 4306.8 & 23766 & -0.05 & $-0.16^{*}$ & 5939.6 & 9965 \\
\hline 74 & 0.00 & -0.22 & 4135.8 & 23511 & 0.00 & -0.01 & 8355.1 & 12034 \\
\hline 77 & 0.04 & 0.02 & 4885.1 & 24038 & 0.07 & 0.02 & 7972.2 & 12707 \\
\hline 78 & 0.09 & -0.06 & 3963.3 & 23766 & $0.24^{\star \star}$ & 0.13 & 5880 & 9447 \\
\hline 79 & -0.07 & -0.06 & 3496.5 & 22831 & 0.15 & -0.09 & 1453.8 & 6576 \\
\hline 84 & 0.04 & 0.16 & 4311.3 & 23239 & $-0.22^{\star \star}$ & -0.03 & 5952.3 & 9351 \\
\hline
\end{tabular}

Notes: Table reports estimates of the coefficients EU and bothEU of the probit and Hausman-Taylor regressions for the sample of EU12, EUC4, and Ukraine in 2000-2007 for selected products at SITC 2 digit level. Same variables as for the aggregate two stage HT regression are included but not reported Time-, exporter, and importer fixed effects are included but not reported. For probit, marginal effects are reported. For HT method, EU and bothEU variables are treated as endogenous.

* $p>0.05,{ }^{* \star} p>0.01$

accession process, while providing results similar to the pair fixed effect method in terms of predicting trade patterns. The industrial structure is captured by an exporting country fixed effect under assumption that composition of industries does not change significantly 
over the investigated period ${ }^{19}$. Table 4 reports the point estimates of the coefficients of $E U_{t}^{i j}$ and bothEU $U_{t}^{i j}$ variables at the first and second stages of the estimation procedure for 24 selected SITC two digit products that are the most important exports of Ukraine in 2000-2007 20 . Unlike on aggregate level, the change in the accession status plays a significant role on exports of some products. In general, the effect varies from sector to sector and can be positive or negative. For example, a change in the EU accession status from a candidate to a member reduces probability and volume of the overall trade in diary products and birds' eggs (SITC code 2), while it increases probability and volume of exports of those products within the EU. As another example, a change in the EU accession status increases the overall export volume of road vehicles (code 78), but has no significant effect on probability and volume of trade within the EU.

\subsection{Forgone export gains due to non-integration at SITC two- digit level}

This section calculates and reports forgone gains in the Ukrainian export under the EU1 and EU2 scenarios against the benchmark CIS scenario. First, we generate a dataset with predicted exports of sector $\mathrm{k}$ to region $\mathrm{j}$ at time $\mathrm{t}, T E_{\text {skt }}^{j}$, under the three scenarios: $\mathrm{s}=\{\mathrm{EU} 1, \mathrm{EU} 2, \mathrm{CIS}\}$. Second, the percentage change is calculated according to the following formula: $\Delta_{s k}^{j}=100 \% \frac{T E_{s k}^{j}-T E_{C I S k}^{j}}{T E_{C I S k}^{i}}, s=E U 1, E U 2$.

Figure 3 summarizes how the export gains would evolve over time across four large product groups: agriculture and food, chemicals and processed materials, manufactured goods, and raw materials ${ }^{21}$. According to the results, by 2007, Ukraine would have almost doubled export of manufactured goods under the EU2 scenario. This result comes despite the fact that in 2000 the exports of manufactured goods under the

\footnotetext{
${ }^{19}$ Alternatively, we constructed shares of the value added of each SITC two digit product in the total value added based on Global Trade Analysis Project (GTAP) input-output tables. It does not have a significant impact on our main findings but have two serious drawbacks. For most countries in the sample, the inputoutput tables are available for only one year. In addition, Moldova and Macedonia are not in the GTAP7 database. Given the drawbacks, this approach reduces the sample size and precludes us from using of exporting counties fixed effects.

${ }^{20}$ Products were rank according to the total value of export in 2000-2007.

${ }^{21}$ Agriculture and food (SITC 1 digit codes 0,1, and 2), Chemicals and processed materials (codes 5 and 6), Manufactured goods (codes 7 and 8), Raw materials (codes 3 and 4).
} 
EU2 scenario is $50 \%$ lower than under the CIS scenario! Other groups of products does not have such a clear trend but tend to have negative gains at the early stages of the integration process and positive gains at the later stages. Also, the EU2 scenario generates slightly higher gains than the EU1 scenario.

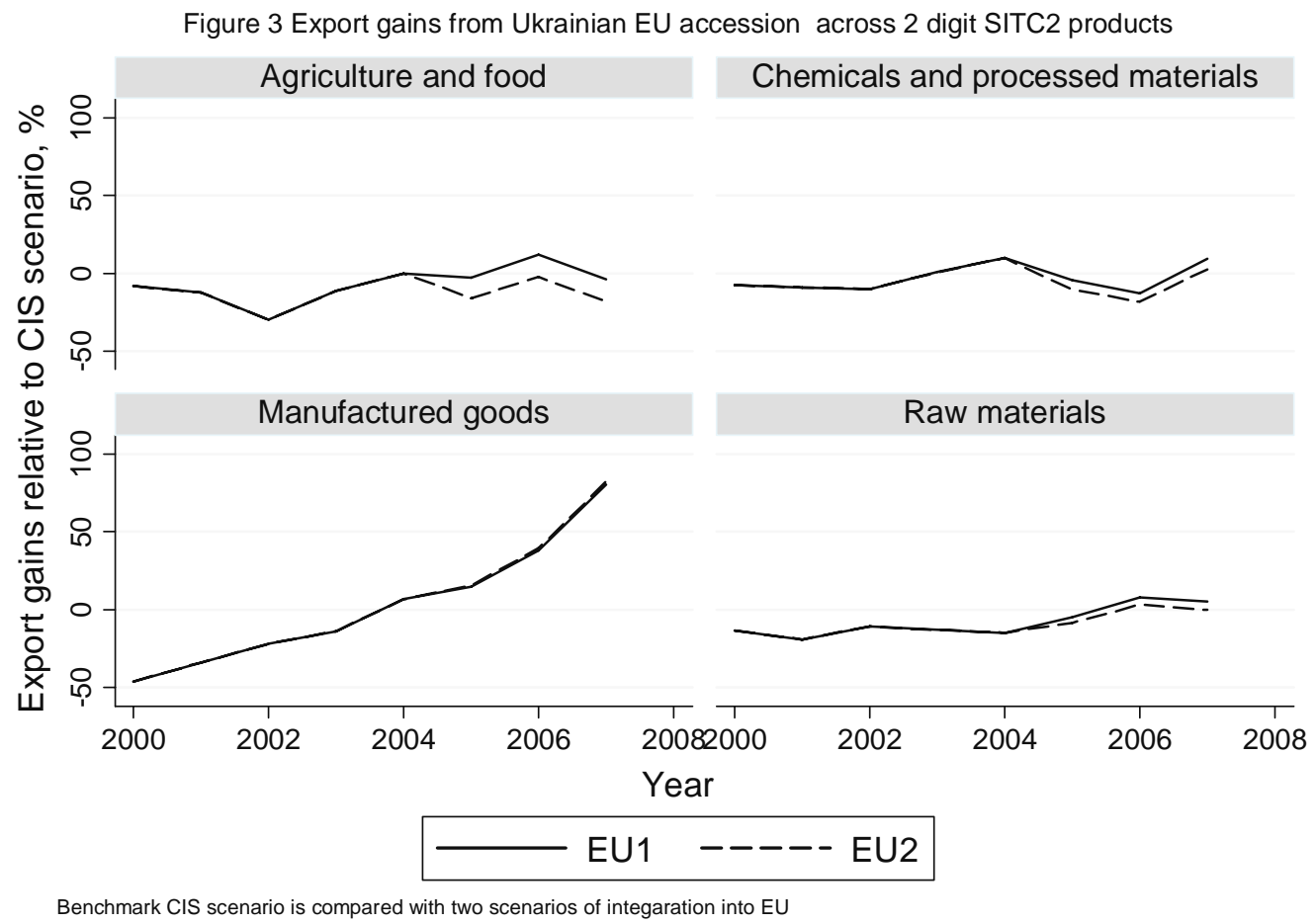

Table 5 presents more disaggregated results for the 24 most important products to the five groups of countries: CIS, EU12, EU15, RoE (Rest of Europe), RoW (Rest of the world). The highest expected benefits of the Ukraine integrating into the EU would have come from a substantial increase in exports of various types of machinery and equipment (codes 71, 72, and 74), road vehicles and transport equipment (codes 78 and 79), and apparel and closing accessories (code 84). These gains would have been virtually uniformly positive across all groups of countries and economically large. As an example, the Ukraine would have increased export of road vehicles (code 78) to the CIS countries by 70 percent under the EU1 scenario and by 88 percent under the EU2 scenario, while export to the EU15 would have been increased by 60 and 82 percent respectively. The export of raw materials, on the other hand, would have either declined as, for example, export of petroleum and its products (code 33) or remained relatively stable as export of 
iron and steel (code 67). However, the export of manufactures of steel (code 69), one of the most important articles of the Ukrainian export, would have increased uniformly.

Another important group of products where Ukraine could have potentially gained is food and agriculture. The gains would have been positive for exports to the EU countries but mostly negative for exports to other group of countries. Also, gains would have been significantly higher under a more optimistic EU2 scenario. For example, realization of the EU2 scenario would have increased exports of diary products (code 2) and cereals (code4) to EU15 countries by 95 percent and 14 percent under the EU2 scenario and by 38 percent and 4 percent under the EU1 scenario. At the same time, Ukraine would have substantially reduced exports of food and agricultural products to CIS countries under both scenarios of the European integration. For example, in diary products the export to CIS would have reduced by 20 percent under the EU1 scenario and by 31 percent under the EU2 scenario. Given the mixed evidence, there are no apparent benefits of joining EU for the agriculture and food industry.

Change in the composition of exports towards manufactured products is a positive development for, at least, two reasons. First, experimenting with production of new varieties, a developing country learns its comparative advantage in a competitive environment with high uncertainty about the demand for new products (Hausmann and Rodrik, 2003). As a result, higher share of high quality goods in export is associated with higher future economic growth (Hausmann, Hwang, and Rodrik, 2007). Second, moving away from exporting primary commodities towards exporting manufactured products is desirable because of a general trend towards a decline in terms of trade of primary commodities (Athukurola, 2000).

A disaggregated analysis also agrees with the analysis of the aggregate export on virtually no gains from the EU integration in terms of the cumulative aggregate export in 2000-2007 because the substantial gains in exports of manufactured goods at the later stages of integration are counter-balanced by losses at the early stages. However, the strong upward trend in manufactured goods clearly indicates that over time the benefits of integration accumulate very rapidly. 
Table 5 Export gains from EU integration

\begin{tabular}{|c|c|c|c|c|c|c|c|c|c|c|}
\hline \multirow{3}{*}{ SITC2 } & \multicolumn{10}{|c|}{ Region } \\
\hline & \multicolumn{2}{|c|}{ CIS } & \multicolumn{2}{|c|}{ EU12 } & \multicolumn{2}{|c|}{ EU15 } & \multicolumn{2}{|c|}{ RoE } & \multicolumn{2}{|c|}{ RoW } \\
\hline & EU1, \% & EU2, \% & EU1, \% & EU2, \% & EU1, \% & EU2, \% & EU1, \% & EU2, \% & EU1, \% & EU2, \% \\
\hline 2 & -20.3 & -31.0 & -6.6 & 33.0 & 38.2 & 94.7 & -6.1 & -11.1 & -13.7 & -14.8 \\
\hline 4 & -17.9 & -22.0 & -0.1 & 9.2 & 4.3 & 13.6 & 1.8 & -3.8 & -4.9 & -10.5 \\
\hline 22 & -15.4 & -13.0 & 1.1 & 10.7 & 10.0 & 19.1 & 11.2 & 14.2 & -3.4 & -1.9 \\
\hline 24 & -11.6 & -13.4 & -8.6 & -12.5 & -4.4 & -7.1 & -3.8 & -5.8 & 2.2 & 1.2 \\
\hline 27 & -6.5 & -9.3 & -1.9 & -6.2 & 19.3 & 14.8 & 2.6 & -0.6 & -1.7 & -3.8 \\
\hline 28 & -1.0 & -0.8 & -0.2 & 9.0 & 0.4 & 8.3 & 30.5 & 30.7 & -6.8 & -6.7 \\
\hline 32 & 0.9 & 14.3 & -1.1 & -2.5 & 7.4 & 5.9 & -1.2 & 12.3 & 16.8 & 32.7 \\
\hline 33 & 7.5 & -8.2 & -11.3 & -15.2 & -11.2 & -14.9 & -2.9 & -18.8 & 2.1 & -12.1 \\
\hline 42 & -12.0 & -25.2 & -17.2 & -16.6 & -32.0 & -31.5 & -29.8 & -37.1 & -34.0 & -40.3 \\
\hline 51 & 0.4 & 7.9 & -12.0 & -6.0 & -14.0 & -8.9 & 11.3 & 20.2 & -3.4 & 3.2 \\
\hline 52 & -10.2 & -15.1 & -5.0 & -5.8 & -2.2 & -3.0 & 9.5 & 1.9 & -2.5 & -7.2 \\
\hline 56 & -9.8 & -13.7 & -6.5 & -10.4 & 9.7 & 6.0 & 15.5 & 9.6 & -10.6 & -13.7 \\
\hline 64 & -20.9 & -30.5 & -11.9 & -16.0 & 4.0 & -0.7 & -3.4 & -12.3 & 0.4 & -3.4 \\
\hline 66 & -16.4 & -15.8 & -3.4 & 1.9 & -6.3 & -3.4 & -13.4 & -12.8 & -1.2 & -0.8 \\
\hline 67 & 10.6 & 3.0 & -9.6 & -3.1 & -2.2 & 3.1 & 0.1 & -5.6 & -6.8 & -10.8 \\
\hline 68 & -12.1 & -9.3 & -5.0 & -7.4 & -2.9 & -4.4 & -7.6 & -5.1 & -8.3 & -6.5 \\
\hline 69 & 10.9 & 16.2 & 13.8 & 17.1 & 5.9 & 8.2 & 12.7 & 17.4 & 7.7 & 10.9 \\
\hline 71 & 11.8 & 5.4 & 10.5 & 14.8 & 26.0 & 30.0 & 16.3 & 10.2 & 28.2 & 22.1 \\
\hline 72 & 12.3 & 10.6 & 6.1 & -0.4 & 15.4 & 9.7 & 4.6 & 3.1 & 15.3 & 13.8 \\
\hline 74 & 16.7 & 16.6 & 21.1 & 20.7 & 26.3 & 26.0 & 19.9 & 19.8 & 16.0 & 16.0 \\
\hline 77 & 18.9 & 22.3 & 46.5 & 51.2 & 23.5 & 26.4 & 29.8 & 33.0 & 26.3 & 29.2 \\
\hline 78 & 70.2 & 88.4 & 37.4 & 59.4 & 60.4 & 81.8 & 52.6 & 67.8 & 21.0 & 29.8 \\
\hline 79 & -20.7 & -17.3 & -0.3 & 1.3 & 23.1 & 24.9 & 14.6 & 19.7 & 39.6 & 45.0 \\
\hline 84 & 27.3 & 18.9 & 13.9 & 6.2 & 13.7 & 10.2 & 11.3 & 3.6 & -1.1 & -3.4 \\
\hline Average & 0.5 & -0.9 & 2.1 & 5.5 & 8.9 & 12.9 & 7.3 & 6.3 & 3.2 & 2.8 \\
\hline
\end{tabular}

Notes:Table reports a percentage change in exports of moving from the CIS scenario of integration to the EU1 and EU2 scenarios of integration. The scenarios are EU1 - Ukraine has been announced EU candidate, EU2 - Ukraine has become an EU member in 2004, CIS Ukraine did not integrate with EU. Only 24 most important exports (in terms of total value of actual exports in examined period) are reported. SITC sectors are described in the Table $1 \mathrm{~A}$

First, total export in sector $\mathrm{k}$ in region $\mathrm{i}, T E_{s k}^{i}$, is computed for each of the three scenarios. Next, the percentage changes are calculated according to the following formula: $\Delta_{s k}^{i}=100 \% \frac{T E_{s k}^{i}-T E_{C I S k}^{i}}{T E_{C I S k}^{i}}, s=E U 1, E U 2$ 


\section{Conclusions}

In order to access costs of non-integration of Ukraine in the EU in 2000-2007, we estimate a gravity model at the level of SITC two digit products applying a newly developed two stage procedure that accounts for selection of exporters and firm-level heterogeneity. We introduce and measure two different channels of the effect of integration on trade: a direct effect of integration and an indirect effect of the behavioral change in the parameters of the gravity equation. Two endogenous variables, $E U_{t}^{i}$ and bothEU $U_{t}^{i j}$, capture the former, while differences in the coefficients of the gravity equation estimated for the two different samples capture the latter. The direct effect is found to be important and highly product-specific for disaggregated exports, but non-significant for the aggregate export. The behavioral changes, on the other hand, play an important role in determining export patterns for aggregate as well as disaggregated exports.

We calibrate the estimation method using the aggregate data and show that the two-stage HT and two-stage pair-fixed effect methods generate similar predictions, while a simple OLS method produce highly implausible results. Any integration strategy would be preferable to the current situation of being lost in transition. Yet, the benefits of the EU integration are higher relative to the CIS integration. Therefore, the vector of integration into EU should be supported by Ukrainian policymakers as a better integration strategy.

Moving to the disaggregated data, we estimate the costs of non-integration into the EU bloc relative to the integration into the CIS bloc at the level of SITC two digit products and find that the most losses in terms of foregone exports are expected in manufactured goods with almost doubled exports in 2007 relative to the CIS scenario. As an example, Ukraine would have increased export of road vehicles (code 78) to the CIS countries by 70 percent under the EU1 scenario and by 88 percent under the EU2 scenario, while export to the EU15 would have increased by 60 and 82 percent respectively. Under the EU2 scenario, Ukraine would have also increased export of diary products and cereals to EU15 countries by 95 and 15 percent respectively, but would 
have lost CIS markets which make the overall effect of EU integration on agriculture and food exports quite ambiguous.

There are several important directions for future work. The paper looks at the impact of the EU integration on exports, while integration can have important effects on imports, labor market, foreign direct investments, and economic growth. Also the paper did not discuss the supply side of membership. It simply assumes that Ukraine could join at some point if it is beneficial for the country. However, an important question is: would it be beneficial for EU to integrate Ukraine? To answer this question requires an analysis of costs and benefits of Ukrainian accessions for current EU members.

\section{Literature}

Aitken, N. (1973). The Effect of the EEC and EFTA on European Trade: A Temporal Cross-Section Analysis. American Economic Review, 63(5), 881-892.

Anderson, J., \& van Wincoop, E. (2003). Gravity with Gravitas: A Solution to the Border Puzzle. American Economic Review, 93(1), 170-192.

Athukurola, P.C. (2000). Manufacturing exports and terms of trade of developing countries: Evidence from Sri Lanka. Journal of Development Studies, 36, 89-104 Baier, S., \& Bergstrand, J. (2004). Economic Determinants of Free Trade Agreements. Journal of International Economics, 64(1), 29-63.

Baldwin, R., \& Taglioni, D. (2006). Gravity for Dummies and Dummies for Gravity Equations. NBER working papers: 12516

Baldwin, R. (2006). Multilateralising Regionalism: Spaghetti Bowls as Building Blocs on the Path to Global Free Trade. World Economy, 29(11), 1451-1518.

Baldwin, R., Francois, J., \& Portes, R. (1997). The Costs and Benefits of Eastern Enlargement: The Impact on the EU and Central Europe. Economic Policy: A European Forum, (24), 125-170.

Baldwin, R. (1995). The Eastern Enlargement of the European Union. European Economic Review, 39(3-4), 474-481.

Baldwin, R., \& Venables, A. (1995). Regional Economic Integration. Handbook of international economics. Volume 3 (pp. 1597-1644). Handbooks in Economics, vol. 3.

Baldwin, R. (1994). Towards an integrated Europe. London: Center for Economic Policy Research

Baldwin, R. E. (1993). 'A Domino Theory of Regionalism', NBER Working Paper 4465 
(Cambridge). Published as: Baldwin, R. E. (1995), 'The Domino Theory of Regionalism', in R. E. Baldwin, P. Haaparanta and K. Kiander (eds.), Expanding Membership of the European Union (Cambridge: Cambridge University Press).

Baldwin, R., Begg, D., Danthine, J., Grilli, V., Haaland, J., Neumann, M., Norman, V., Venables, A. and Winters, L. 1992. Is Bigger Better ? The Economics of EC Enlargement. Monitoring European Integration 3. London, Centre for Economic Policy Research. http://www.cepr.org/pubs/books/P054.asp

Bernard, Andrew B., Eaton, J, Jensen, JB, and S Kortum. (2003). Plants and Productivity in International Trade. American Economic Review, 93(4), 1268-1290.

Bussiere, M., Fidrmuc, J., \& Schnatz, B. (2008). EU Enlargement and Trade Integration: Lessons from a Gravity Model. Review of Development Economics, 12(3), 562-576.

Egger, P., Pfaffermayr, M., \& Schmidt, R. (2007). Trade in Western and Eastern Europe in the Aftermath of COMECON: An Assessment of Behavioral Change. Oxford Economic Papers, 59(1), 102-126.

Gros, D., \& Gonciarz, A. (1996). A Note on the Trade Potential of Central and Eastern Europe. European Journal of Political Economy, 12(4), 709-721.

Hamilton, C., \& Winters, L. (1992). Opening Up International Trade with Eastern Europe. Economic Policy: A European Forum, (14), 77.

Hausman, J., \& Taylor, W. (1981). Panel Data and Unobservable Individual Effects. Econometrica, 49(6), 1377-1398.

Hausmann, R., Hwang, J., \& Rodrik, D. (2007). What You Export Matters. Journal of Economic Growth, 12(1), 1-25.

Hausmann, R., \& Rodrik, D. (2003). Economic Development as Self-Discovery. Journal of Development Economics, 72(2), 603-633.

Helpman, E., Melitz, M., \& Rubinstein, Y. (2008) Estimating Trade Flows: Trading Partners and Trading Volumes. Quarterly Journal of Economics, 123(2), 441-487.

Hummels, David. (1999). Toward a Geography of Trade Costs. GTAP working paper

Kaufmann, D., Kraay, A., \& Mastruzzi, M. (2007). Governance Matters VI: Governance Indicators for 1996--2006. World Bank Policy Research Working Paper No. 4280, Available at SSRN: http://ssrn.com/abstract $=999979$.

Krugman, P., (1991). The Move Toward Free Trade Zones. In: Policy Implications of Trade and Currency Zones, proceedings of a Federal Reserve Bank of Kansas City symposium, pp. $7-41$. 
Nilsson, L. (2000). Trade Integration and the EU Economic Membership Criteria. European Journal of Political Economy, 16(4), 807-827.

Martin, W., \& Pham, C. (2008). Estimating the Gravity Equation when Zero Trade Flows are Frequent. unpublished manuscript.

McPherson, M., \& Trumbull, W. (2008). Rescuing Observed Fixed Effects: Using the Hausman-Taylor Method for Out-of-Sample Trade Projections. International Trade Journal, 22(3), 315-340.

Melitz, M. (2003) The Impact of Trade on Intra-industry Reallocations and Aggregate Industry Productivity. Econometrica, 71(6), 1695-1725.

Mitra, P. (2008) Innovation, Inclusion and Integration: From Transition to Convergence in Eastern Europe and the Former Soviet Union. Washington, D.C.: World Bank

Pelzman, J. (1977). Trade Creation and Trade Diversion in the Council of Mutual Economic Assistance: 1954-70. American Economic Review, 67(4), 713-722.

Serlenga, L., \& Shin, Y. (2007). Gravity Models of Intra-EU Trade: Application of the CCEP-HT Estimation in Heterogeneous Panels with Unobserved Common Time-Specific Factors. Journal of Applied Econometrics, 22(2), 361-381.

Wang, Z., \& Winters, L. (1991). The Trading Potential of Eastern Europe. CEPR Discussion Paper no. 610. London, Centre for Economic Policy Research, http://www.cepr.org/pubs/dps/DP610.asp.

World Bank, (2005) From Desintegration to Reintegration: Eastern Europe and the Former Soviet Union in International Trade. Edited by H. Broadman 


\section{Appendix}

Table A1 SITC2 codes description

\begin{tabular}{|c|c|c|c|}
\hline SITC2 & DESCRIPTION & SITC2 & DESCRIPTION \\
\hline 0 & LIVE ANIMALS OTHER THAN FISH & 55 & ESSENTIAL OILS AND RESINOIDS AND PERFUME \\
\hline 1 & MEAT AND MEAT PREPARATIONS & 56 & FERTILIZERS \\
\hline 2 & DAIRY PRODUCTS AND BIRDS' EGGS & 57 & PLASTICS IN PRIMARY FORMS \\
\hline 3 & FISH, CRUSTACEANS, MOLLUSCS & 58 & PLASTICS IN NONPRIMARY FORMS \\
\hline 4 & CEREALS AND CEREAL PREPARATIONS & 59 & CHEMICAL MATERIALS AND PRODUCTS, N.E.S. \\
\hline 5 & VEGETABLES AND FRUIT & 61 & LEATHER, LEATHER MANUFACTURES, N.E.S. \\
\hline 6 & SUGARS, SUGAR PREPARATIONS AND HONEY & 62 & RUBBER MANUFACTURES, N.E.S. \\
\hline 7 & COFFEE, TEA, COCOA, SPICES & 63 & CORK AND WOOD MANUFACTURES \\
\hline 8 & FEEDING STUFF FOR ANIMALS & 64 & PAPER, PAPERBOARD, AND ARTICLES \\
\hline 9 & MISCELLANEOUS EDIBLE PRODUCTS & 65 & $\begin{array}{l}\text { TEXTILE YARN, FABRICS, MADE-UP ARTICLES, } \\
\text { N.E.S. }\end{array}$ \\
\hline 11 & BEVERAGES & 66 & $\begin{array}{l}\text { NONMETALLIC MINERAL MANUFACTURES, } \\
\text { N.E.S. }\end{array}$ \\
\hline 12 & TOBACCO AND TOBACCO MANUFACTURES & 67 & IRON AND STEEL \\
\hline 21 & HIDES, SKINS AND FURSKINS, RAW & 68 & NONFERROUS METALS \\
\hline 22 & OIL SEEDS AND OLEAGINOUS FRUITS & 69 & $\begin{array}{l}\text { MANUFACTURES OF METALS, N.E.S. } \\
\text { POWER GENERATING MACHINERY AND }\end{array}$ \\
\hline 23 & CRUDE RUBBER & 71 & $\begin{array}{l}\text { EQUIPMENT } \\
\text { MACHINERY SPECIALIZED FOR PARTICULAR }\end{array}$ \\
\hline 24 & CORK AND WOOD & 72 & INDUSTRIES \\
\hline 25 & PULP AND WASTE PAPER & 73 & METALWORKING MACHINERY \\
\hline 26 & TEXTILE FIBERS AND THEIR WASTES & 74 & $\begin{array}{l}\text { GENERAL INDUSTRIAL MACHINERY, N.E.S. } \\
\text { OFFICE AND AUTOMATIC DATA PROCESSING }\end{array}$ \\
\hline 27 & CRUDE FERTILIZERS AND CRUDE MINERALS & 75 & $\begin{array}{l}\text { MACHINES } \\
\text { TELECOMMUNICATIONS AND SOUND }\end{array}$ \\
\hline 28 & METALLIFEROUS ORES AND METAL SCRAP & 76 & RECORDING \\
\hline 29 & $\begin{array}{l}\text { CRUDE ANIMAL AND VEGETABLE MATERIALS, } \\
\text { N.E.S. }\end{array}$ & 77 & $\begin{array}{l}\text { ELECTRICAL MACHINERY AND APPLIANCES, } \\
\text { N.E.S. }\end{array}$ \\
\hline 32 & COAL, COKE AND BRIQUETTES & 78 & $\begin{array}{l}\text { ROAD VEHICLES (INCLUDING AIR-CUSHION } \\
\text { VEHICLES) }\end{array}$ \\
\hline 33 & $\begin{array}{l}\text { PETROLEUM, PETROLEUM PRODUCTS AND } \\
\text { RELATED }\end{array}$ & 79 & TRANSPORT EQUIPMENT, N.E.S. \\
\hline 34 & GAS, NATURAL AND MANUFACTURED & 81 & $\begin{array}{l}\text { PREFABRICATED BUILDINGS; SANITARY, } \\
\text { PLUMBING, HEATING }\end{array}$ \\
\hline 35 & ELECTRIC CURRENT & 82 & $\begin{array}{l}\text { FURNITURE AND PARTS THEREOF; BEDDING, } \\
\text { MATTRESSES }\end{array}$ \\
\hline 41 & ANIMAL OILS AND FATS & 83 & $\begin{array}{l}\text { TRAVEL GOODS, HANDBAGS AND SIMILAR } \\
\text { CONTAINERS } \\
\text { ARTICLES OF APPAREL AND CLOTHING }\end{array}$ \\
\hline 42 & FIXED VEGETABLE FATS AND OILS & 84 & ACCESSORIES \\
\hline 43 & ANIMAL OR VEGETABLE FATS AND OILS & 85 & FOOTWEAR \\
\hline 51 & ORGANIC CHEMICALS & 87 & $\begin{array}{l}\text { PROFSSIONAL, SCIENTIFIC INSTRUMENTS, N.E.S. } \\
\text { PHOTOGRAPHIC APPARATUS; WATCHES AND }\end{array}$ \\
\hline 52 & INORGANIC CHEMICALS & 88 & CLOCKS \\
\hline 53 & DYEING, TANNING AND COLORING MATERIALS & 89 & $\begin{array}{l}\text { MISCELLANEOUS MANUFACTURED ARTICLES, } \\
\text { N.E.S. }\end{array}$ \\
\hline 54 & MEDICINAL AND PHARMACEUTICAL PRODUCTS & & \\
\hline
\end{tabular}


Table A2 EU12, EUC4, and CIS Exports in 2000-2007

\begin{tabular}{|c|c|c|c|c|c|}
\hline Source country & $\begin{array}{c}\text { Number of } \\
\text { Positive Exports }\end{array}$ & $\begin{array}{c}\text { As \% of All } \\
\text { Postitive } \\
\text { Exports in the } \\
\text { Sample } \\
\end{array}$ & $\begin{array}{l}\text { Mean Export, } \\
\text { thosands of } \$ \text { US }\end{array}$ & $\begin{array}{l}\text { Total Export, } \\
\text { billions of \$US }\end{array}$ & $\begin{array}{l}\text { As \% Value } \\
\text { of Total } \\
\text { Export in the } \\
\text { Sample } \\
\end{array}$ \\
\hline & \multicolumn{5}{|c|}{ A. EU12 and EUC4 } \\
\hline Albania & 3870 & 1.0 & 1155 & 4.5 & 0.2 \\
\hline Bulgaria & 30947 & 8.0 & 2364 & 73.2 & 2.7 \\
\hline Cyprus & 15910 & 4.1 & 501 & 8.0 & 0.3 \\
\hline Czechia & 38788 & 10.0 & 13034 & 506.0 & 18.3 \\
\hline Estonia & 21214 & 5.5 & 2302 & 48.8 & 1.8 \\
\hline Croatia & 20002 & 5.1 & 2945 & 58.9 & 2.1 \\
\hline Hungary & 32408 & 8.3 & 12519 & 406.0 & 14.7 \\
\hline Lithuania & 23293 & 6.0 & 3140 & 73.1 & 2.6 \\
\hline Latvia & 18152 & 4.7 & 1738 & 31.6 & 1.1 \\
\hline Macedonia & 9627 & 2.5 & 1484 & 14.3 & 0.5 \\
\hline Malta & 10983 & 2.8 & 1733 & 19.0 & 0.7 \\
\hline Poland & 34990 & 9.0 & 16134 & 565.0 & 20.5 \\
\hline Romania & 27254 & 7.0 & 6419 & 175.0 & 6.3 \\
\hline Slovakia & 25799 & 6.6 & 8481 & 219.0 & 7.9 \\
\hline Slovenia & 27420 & 7.1 & 4442 & 122.0 & 4.4 \\
\hline Turkey & 47853 & 12.3 & 9081 & 435.0 & 15.8 \\
\hline \multirow[t]{2}{*}{ EU12 plus EUC4 } & 388510 & 100.0 & 7097 & 2760.0 & 100.0 \\
\hline & \multicolumn{5}{|c|}{ B. CIS } \\
\hline Armenia & 5426 & 4.3 & 998 & 5.4 & 0.3 \\
\hline Azerbaijan & 7448 & 5.9 & 3891 & 29.0 & 1.7 \\
\hline Byelarus & 16250 & 12.9 & 6356 & 103.0 & 6.2 \\
\hline Georgia & 6795 & 5.4 & 759 & 5.2 & 0.3 \\
\hline Kazakhstan & 11465 & 9.1 & 14203 & 163.0 & 9.8 \\
\hline Kyrgyzstan & 5272 & 4.2 & 1002 & 5.3 & 0.3 \\
\hline Moldova & 7711 & 6.1 & 894 & 6.9 & 0.4 \\
\hline Russia & 36876 & 29.3 & 30789 & 1140.0 & 68.3 \\
\hline Ukraine & 28404 & 22.6 & 7773 & 221.0 & 13.2 \\
\hline $\mathrm{CIS}$ & 125647 & 100.0 & 13323 & 1670.0 & 100.0 \\
\hline
\end{tabular}

Note: SITC 2 digit exports of EU12, EUC4, and CIS to 179 countries in 2000-2007.

Source: COMTRADE 